\title{
TESES
}

\section{Distinção, cultura de consumo e gentrificação: o Centro Cultural Banco do Brasil e o mercado de bens simbólicos}

Marco Estevão de Mesquita Vieira

Curso: Doutorado em Sociologia

Data de defesa: 5 de abril de 2006

Orientadora: $\operatorname{Prof}^{\mathrm{a}} \mathrm{Dr}^{\mathrm{a}}$ Mariza Veloso Motta Santos

\section{Resumo}

O trabalho analisa as condições de emergência dos centros culturais a partir do estudo de caso sobre o Banco do Brasil, a principal instituição financeira do País, que, por ser pioneira na criação de centros culturais corporativos, estabeleceu o paradigma que passou a conduzir os processos de enobrecimento urbano dos centros metropolitanos brasileiros.

A partir da história do Banco do Brasil e de sua ambigüidade de atuação, ora como agente de políticas publicas, ora como banco comercial, o trabalho analisa as estratégias desenvolvidas pela empresa para manter posição ante as perdas processadas com a criação do Banco Central e as ameaças de privatização decorrente da reestruturação capitalista da década de 1980 e do domínio do pensamento neoliberal. Identifica a série discursiva que moldou a invenção de suas tradições e as motivações para instalar um centro cultural na sua antiga sede no Rio de Janeiro. 
O sucesso do empreendimento possibilitou recuperar o centro histórico da cidade, fato que transformou o Centro Cultural Banco do Brasil (CCBB) em âncora do Corredor Cultural, projeto de requalifacação urbana do Rio de Janeiro. Sob esse aspecto, o trabalho analisa as afinidades eletivas entre os interesses da empresa e do município e os resultados e as limitações do projeto de reurbanização carioca, suas conseqüências para o surgimento de processos semelhantes nas demais capitais brasileiras e os seus elos com os pressupostos da pós-modernidade.

A bem-sucedida ação da política urbana carioca levou as demais metrópoles brasileiras a exigir do Banco do Brasil igualdade de tratamento, dando início a uma disputa que levou a instituição a criar novos CCBB em São Paulo e Brasília. Nesse tópico, o trabalho analisa o processo de expansão dos $\mathrm{CCBB}$ e as novas orientações mercadológicas que o transformaram em moeda de troca. Estuda também a consolidação da era dos museus e centros culturais no Brasil sob o conceito de distinção e do mercado de bens simbólicos e como conseqüência das ações para tornar as cidades elegíveis para investimentos e trânsito dos agentes da globalização econômica.

Palavras-chave: centro cultural, cultura, política urbana. 